\title{
Governance in Russian Regions: A Policy Comparison
}

Sabine Kropp, Aadne Aasland, Mikkel Berg-Nordlie, Jørn Holm-Hansen \& Johannes Schumann (red.)

Basingstoke: Palgrave Macmillan 2018

249 sider. ISBN 9783319617015

Omtalt av Helge Blakkisrud [seniorforsker, leder for Forskningsgruppen for Russland, Asia og internasjonal handel, Norsk Utenrikspolitisk Institutt (NUPI), hb@nupi.no]

Dagens Russland fremstilles ofte som styrt gjennom en "maktvertikal» med utspring i Kreml, en sentralisert og hierarkisk organisering av utøvende makt hvor Putin bestemmer, og beslutningene deretter kanaliseres ned gjennom beslutningskjeden på føderalt og regionalt nivå inntil de til slutt iverksettes på det aktuelle politikkområdet. Men virkeligheten er ikke alltid så enkel. Det skal ikke mer til enn en rask kikk i en hvilken som helst russisk avis for å finne eksempler på halvhjertet gjennomføring og ikke-intenderte resultater av Kremls politikk.

Det har vært gjort flere forsøk på å forklare de ofte nedslående resultatene når det kommer til gjennomføringsevne. Daniel Treisman mener vi må skille mellom den dagligdagse "normale politikken» og forekomsten av "manuell kontroll» (rutsjnoje upravlenije) (The New Autocracy, 2018). Det er i sistnevnte tilfelle Putin griper inn og skjærer gjennom, og hvor maktvertikalen lever opp til sitt navn. Men også i Russland er det flest hverdager - med dertil hørende politiske prosesser preget av «vicious competition between bureaucratic factions, business actors, regional elites, and powerful individuals» (Treisman 2018: 16).

Det er nettopp i denne «normale» politikken Sabine Kropp og kollegaer har gjort et dypdykk i Governance in Russian Regions. Sammen med et knippe kollegaer, inkludert Aadne Aasland, Mikkel Berg-Nordlie og Jørn Holm-Hansen fra NIBR, OsloMet, har hun systematisk gått gjennom en rekke politikkområder for å undersøke i hvilken grad organisasjoner, eksperter og interessegrupper er med på å påvirke politikkutforming på regionalt nivå i dagens Russland.

Gjennom syv studier av ulike politikkområder undersøker forfatterne forekomsten av nettverksbasert styring på regionalt nivå. Aadne Aasland og Anastasia Meylakhs har valgt å fokusere på forebygging av HIV blant narkotikamisbrukere, Johannes Schumann og Sabine Kropp på bruk av miljøkonsekvensanalyser, Jørn 
Holm-Hansen og Mikkel Berg-Nordlie på regional klimatilpasning, Jørn Holm Hansen på barnevern, Sabine Kropp og Johannes Schumann på etniske konflikter og Mikkel Berg-Nordlie på representasjon av urfolk. Casene spenner med andre ord vidt.

Tilnærmingen er konsekvent komparativ. Ikke bare trekkes det i det avsluttende kapitlet lærdom på tvers av de ulike politikkområdene. Med ett unntak er også alle case komparative i den forstand at forfatterne sammenligner praksis på samme politikkfelt i ulike deler av Russland. I innledningskapitlet opplyses det at forfatterne i perioden 2007 til 2015 har gjennomført til sammen mer enn 200 semistrukturerte intervjuer og over 20 subcasestudier i syv ulike regioner: Murmansk, Arkhangelsk, St. Petersburg, Saratov, Samara, Krasnodar og Irkutsk. Som om ikke det var nok, fremkommer det i den videre lesningen av boken at de faktisk har dekket enda flere regioner, herunder Moskva, Stavropol og Komi. Det er med andre ord et svært omfattende datainnsamlingsarbeid som ligger til grunn for analysen.

Mulighetene for sammenligning på tvers styrkes også ved at alle forfatterne, om enn i noe varierende grad, forholder seg til det samme teoretiske rammeverket: den i en russisk sammenheng - slik forfatterne selv påpeker - kanskje noe uheldig benevnte "NATO-modellen». Akronymet «NATO» står i denne sammenheng for «nodality» (plassering i nettverket med tanke på informasjonsflyt/kontroll), "authority» (formell autoritet til å treffe beslutninger), "treasure» (kontroll over økonomiske ressurser) og "organisation» (sosiale og menneskelige ressurser). Til sammen fanger rammeverket opp fire sentrale dimensjoner ved hvilke ressurser nettverksmedlemmene kan mobilisere (s. 16).

Presentasjonen av nettverkene er basert på «tykk beskrivelse». Noen ganger kan kanskje detalinivåt, de mange akronymene og henvisninger til lover og reguleringer gå på bekostning av tilgjengelighet og leseopplevelsen. Best er etter min mening kapitlene som lykkes med å kombinere innblikk i nettverkenes indre liv i form av intervjumateriale og observasjoner med en systematisk diskusjon av de ulike dimensjonene av NATO-modellen. For leseren kunne det også vært nyttig om alle kapittelbidragene hadde vært utstyrt med oppsummerende tabeller som eksplisitt plasserte subcasene inn i rammeverket (jf. kapittel 4, 5 og 7). Når det er sagt: De ulike casene bygger på studier gjennomført som del av en rekke ulike prosjekter og over en lengre tidsperiode (2007-2015). Med dette i bakhodet har redaktørene lykkes godt med å sy sammen de ulike kapitlene til et enhetlig format.

I utgangspunktet fremstår ikke-hierarkiske, nettverksbaserte styringsmodeller som diametralt motsatt av alt det maktvertikalen står for. Teoribyggingen rundt slike nettverk har også i utgangspunktet vært basert på empiriske erfaringer fra demokratiske stater. Kan slike tilnærminger likevel bidra til å kaste nytt lys på hvordan regionale myndigheter i dagens Russland forholder seg til ulike sivilsamfunnsaktører, eksperter og næringslivsinteresser? Ja, hevder forfatterne, også myndighetene i autoritære stater, og ikke minst i hybridregimer, står overfor de samme problemene som i demokratier. Saksfeltene blir stadig mer komplekse, ikke-statlige aktører sitter 
på nødvendig kompetanse, og det er også behov for å legitimere politikken. Nettverk er dermed viktige også $\mathrm{i}$ en russisk sammenheng, selv om det må justeres for den politiske konteksten.

Forfatterne avdekker store forskjeller mellom de ulike politikkområdene. Mens Schumann og Kropp i kapittel 4 kan vise til lovfestet deltakelse i miljøkonsekvensutredninger, finner Berg-Nordlie og Holm-Hansen (kapittel 5) få spor av nettverk i regionalt klimatilpasningsarbeid. På enkelte områder opptrer nettverkene som relativt autonome enheter, andre ganger kan det virke som om de utelukkende etableres for å tilfredsstille formelle, eksternt pålagte krav. I slike tilfeller fylles gjerne nettverkene av GONGO-er (government-organised non-governmental oganisations) og andre allierte. Av og til ender det opp med rene potjomkinkulisser hvor formålet først og fremst er å «illuminate the figure of the governor» (s. 177).

Felles for alle studiene på tvers av politikkområder er imidlertid at staten, representert ved regionale myndigheter, inntar en dominerende rolle gjennom «myke» og/ eller «harde» former for «metagovernance». Uavhengig av område og type nettverk er det dessuten gjennomgående en sterk asymmetri mellom hvilke ressurser statlige og ikke-statlige representanter kan mobilisere. For de ikke-statlige aktørenes vedkommende er det først og fremst tilgang som gjelder - til offisiell informasjon, men også til økonomiske ressurser og mulighet for å spille inn kompetanse og ekspertise.

Samlet sett bidrar Governance in Russian Regions til en empirisk basert korreksjon av oppfatningen av maktvertikalens funksjon og russisk styresett. Samtidig er det viktig ikke å trekke dette for langt. Det er «makta som rår». De ikke-statlige aktørene gir et viktig bidrag, men på maktvertikalens premisser. De russiske nettverksbaserte styringsmodellene inkluderer aldri formell styringsmyndighet - denne forblir trygt forankret i vertikalen. De ikke-statlige aktørene er der for å fylle en oppgave, ikke for å kritisere eller formulere politikk. Som to av redaktørene konkluderer: «The Russian version of governance networks is specific insofar as it is applied both to mobilise participation and cooperation, and to keep civil society under control» (s. 238). 